\title{
The Profitablity Graph Of Financing Companies In Indonesia
}

\author{
Ade Fatma Lubis ${ }^{1}$, Mutia Ismail ${ }^{1}$, Zainal Abidin Tarigan ${ }^{1}$, Tapi Andasari Lubis ${ }^{1}$ and Iskandar \\ Muda $^{2}$ \\ \{adefatma@usu.ac.id\} \\ ${ }^{1}$ Accounting Department, Faculty of Economics and Business, Universitas Sumatera Utara, \\ Medan, Indonesia
}

\begin{abstract}
The purpose of this research is to understand the profitability of finance companies in Indonesia. The method of research using a time series analysis. The data used are secondary data sourced from the Financial Sevices Authority. The method of analysis used in this research is the graph method using Smart PLS software. The results show that the profitability of finance companies in Indonesia has decreased in the graph of financing profitability in the previous period.
\end{abstract}

Keywords: Profitability Graph, Net Income, Income Statement

\section{Introduction}

Technical analysis is a method for predicting future price movements and market trends or securities by studying the graph of past market actions by considering the instrument market price and interest in the instrument. Technical analysis is one analysis or approach method that evaluates the movement of a stock price, futures contract, index and several other financial instruments. In short, technical analysis can be said to be a securities analysis using historical price and volume charts. Users of technical analysis are commonly referred to as chartists. Users believe that a stock's market trends and action signals can be obtained based on certain shapes and patterns from the stock price chart (Hu et al., 2017; de Souza et al., 2018). Another form of this analysis is the use of analytic lines applied to price charts according to individual users' opinions. Therefore the basis of transaction decision making is usually also determined based on the judgment and interpretation of the user on a graph. Given its highly subjective nature, this analysis contains more art than the scientific elements. Likewise, according to each user this analysis is also specific to each security. This group of analysts can be classified into a price line analyzer and a pattern analyzer. Users of this analysis are also commonly referred to as technicians. Users believe that the trends and market action signals of a stock can be obtained based on chart patterns that are determined or indicated from quantitative calculations, not subjective interpretations of a chart's shape and pattern (Utami, Nugroho and Farida, 2017; Edwards, Magee and Bassetti, 2018; Namdari and Li, 2018). Given its quantitative nature, this method can be scientifically tested for its ability and performance in generating profits for investors. Another factor that benefits from this modern technical analysis is that the indicator can be programmed automatically using computer assistance. Broadly speaking, these technical indicators can be grouped into trend following indicators and oscillator indicators. Technical analysts and chartits use charts to analyze a large number of securities and predict future price movements. The term "securities" refers to any financial instruments that can be exchanged or quantifiable indices such as stocks, bonds, commodities, futures or market indices. A security with price data more than one time period can be used to 
create a graph for analysis. Weekly data is made from compressed data to show each week as a single data point. The difference between the two can be seen in the graph above. 100 data points (periods) in the daily chart are the same as the last 5 months on the weekly chart, which is indicated by data marked in quadrilateral. The more data that is compressed, the longer the time period for the data displayed. If a daily chart can display 100 data points, then one weekly chart can display 100 weeks (almost 2 years). A daily chart that displays 100 days represents about 5 months of data. There are around 20 days of transactions in a month and around 252 days of transactions a year. The choice of data is straightforward and the duration depends on the availability of data and their respective styles. Traders usually concentrate on daily charts and intraday data to forecast short-term price movements. The shorter the time period and the less data is compressed, the more available data will be available. Because of the more detail, the short-term charts will become more volatile and more disturbances (Arthur et al., 1997; Herawati and Putra, 2018; Soon et al., 2018). Broad price movements, wide high-low prices and a price gap can affect volatility, which can distort the whole picture. Investors usually focus on weekly and monthly charts to mark long-term trends and forecast price movements. Because long-term graphs (1-4 years) describe data that is compressed over a longer period of time, the stock price does not look extreme and often there is little interference. Other strategies can use a combination of long-term and short-term charts. Long-term graphics are very good to use in analyzing a broad picture to get perspective from historical data prices. When the general picture can be analyzed, the daily chart can be used to see the last few months.

\section{Literature Review}

The graph is used by technical analysts, whereas in fact the use of graphics is not only limited to technical analysis. The graph represents stock price movements over a period of time that is easy to read, where this is also a good benefit for fundamental analysts. A graph of historical data will make it easier to signal the effect of an event key on the price of a security, which is displayed more than one time period, both transactions approach the highest, lowest, or between them. The time period is used to form a graph that depends on the type of data: intraday, daily, weekly, monthly, quarterly (4 months), or yearly. The less time the data is, the more detailed it will look. Daily data is made from compressed intraday data to show each day as a single data point.

\section{Methods}

Descriptive method is a method of examining the status of a group of people, an object, a set of conditions, a system of thought or a class of events in the present. The purpose of this descriptive research is to make a systematic, factual and accurate description, description, or painting of the facts, traits and relationships between the phenomena investigated. This study uses secondary data The research sites were at from 2016 to 2017 from Financial Authority Services. The data used in this research were time series secondary data. The hypothesis was tested using Structural Equation Modeling (SEM) with the aid of PLS software. which was one of the multivariate analyses capable of analyzing the variable relationships in complex manner (Yahya, Torong and Muda, 2017). 


\section{Result And Discussion}

\subsection{Measurment Model}

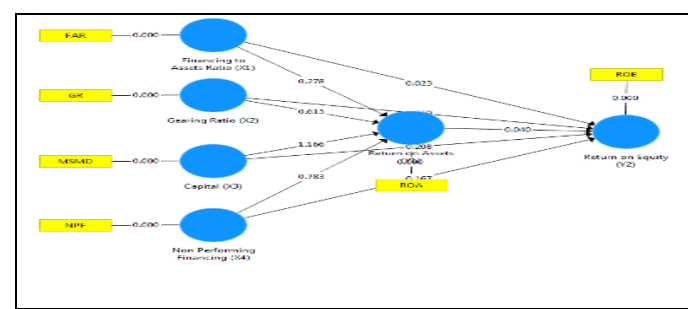

Fig. 1. Standardization Coefficient

\subsection{Evaluation of Regression Weight for Causality Test}

The processing of data with analysis structural equation model using the SmartPLS tool obtained the results of the analysis on the relationship between variables as listed in the following Table 1:

Table 1. Regression Weights

\begin{tabular}{|c|c|c|c|c|c|}
\hline & $\begin{array}{l}\text { Original } \\
\text { Sample } \\
\text { (O) }\end{array}$ & $\begin{array}{l}\text { Sample } \\
\text { Mean } \\
(\mathrm{M})\end{array}$ & $\begin{array}{l}\text { Standard } \\
\text { Deviation } \\
\text { (STDEV) }\end{array}$ & $\begin{array}{c}\text { t Statistics } \\
(\mid \mathrm{O} / \mathrm{STDE} \\
\mathrm{V} \mid)\end{array}$ & $\begin{array}{c}\mathbf{p} \\
\text { Value } \\
\mathbf{s}\end{array}$ \\
\hline $\begin{array}{l}\text { Capital (X3) -> } \\
\text { Return on Assets } \\
\text { (Y1) }\end{array}$ & $-0,269$ & $-0,273$ & 1,644 & 0,164 & 0,870 \\
\hline $\begin{array}{l}\text { Capital (X3) -> } \\
\text { Return on Equity } \\
\text { (Y2) }\end{array}$ & $-0,059$ & $-0,216$ & 0,839 & 0,070 & 0,944 \\
\hline $\begin{array}{l}\text { Financing } \\
\text { Assets Ratio (X1) - } \\
>\quad \text { Return on } \\
\text { Assets (Y1) }\end{array}$ & $-0,074$ & $-0,098$ & 1,652 & 0,045 & 0,964 \\
\hline $\begin{array}{l}\text { Financing } \\
\text { Assets Ratio (X1) - } \\
>\quad \text { Return on } \\
\text { Equity (Y2) }\end{array}$ & $-0,004$ & $-0,005$ & 0,822 & 0,005 & 0,996 \\
\hline $\begin{array}{l}\text { Gearing Ratio } \\
\text { (X2) -> Return on } \\
\text { Assets (Y1) }\end{array}$ & $-0,148$ & $-0,202$ & 0,240 & 0,615 & 0,539 \\
\hline $\begin{array}{l}\text { Gearing Ratio } \\
\text { (X2) -> Return on } \\
\text { Equity (Y2) }\end{array}$ & 0,975 & 0,590 & 0,566 & 1,722 & 0,086 \\
\hline $\begin{array}{l}\text { Non Performing } \\
\text { Financing (X4) -> } \\
\text { Return on Assets } \\
\text { (Y1) }\end{array}$ & $-0,210$ & $-0,326$ & 0,280 & 0,751 & 0,453 \\
\hline $\begin{array}{l}\text { Non Performing } \\
\text { Financing (X4) -> }\end{array}$ & $-0,060$ & $-0,317$ & 0,386 & 0,156 & 0,876 \\
\hline
\end{tabular}




\begin{tabular}{lccccc}
\hline & $\begin{array}{c}\text { Original } \\
\text { Sample } \\
(\mathbf{O})\end{array}$ & $\begin{array}{c}\text { Sample } \\
\text { Mean } \\
(\mathbf{M})\end{array}$ & $\begin{array}{c}\text { Standard } \\
\text { Deviation } \\
\text { (STDEV) }\end{array}$ & $\begin{array}{c}\text { t Statistics } \\
(\mid \mathbf{O} / \text { STDE } \\
\text { V|) }\end{array}$ & $\begin{array}{c}\mathbf{p} \\
\text { Value } \\
\text { s }\end{array}$ \\
\hline $\begin{array}{l}\text { Return on Equity } \\
\text { (Y2) }\end{array}$ & & & & & \\
\hline $\begin{array}{l}\text { Return on Assets } \\
\text { (Y1) }>\text { Return on }\end{array}$ & $-0,013$ & $-0,070$ & 0,354 & 0,038 & 0,970 \\
Equity (Y2) & & & & & \\
\hline
\end{tabular}

Sources : PLS result test. (2018).

The results show that the profitability of finance companies in Indonesia has decreased in the graph of financing profitability in the previous period in the following Figure 2.

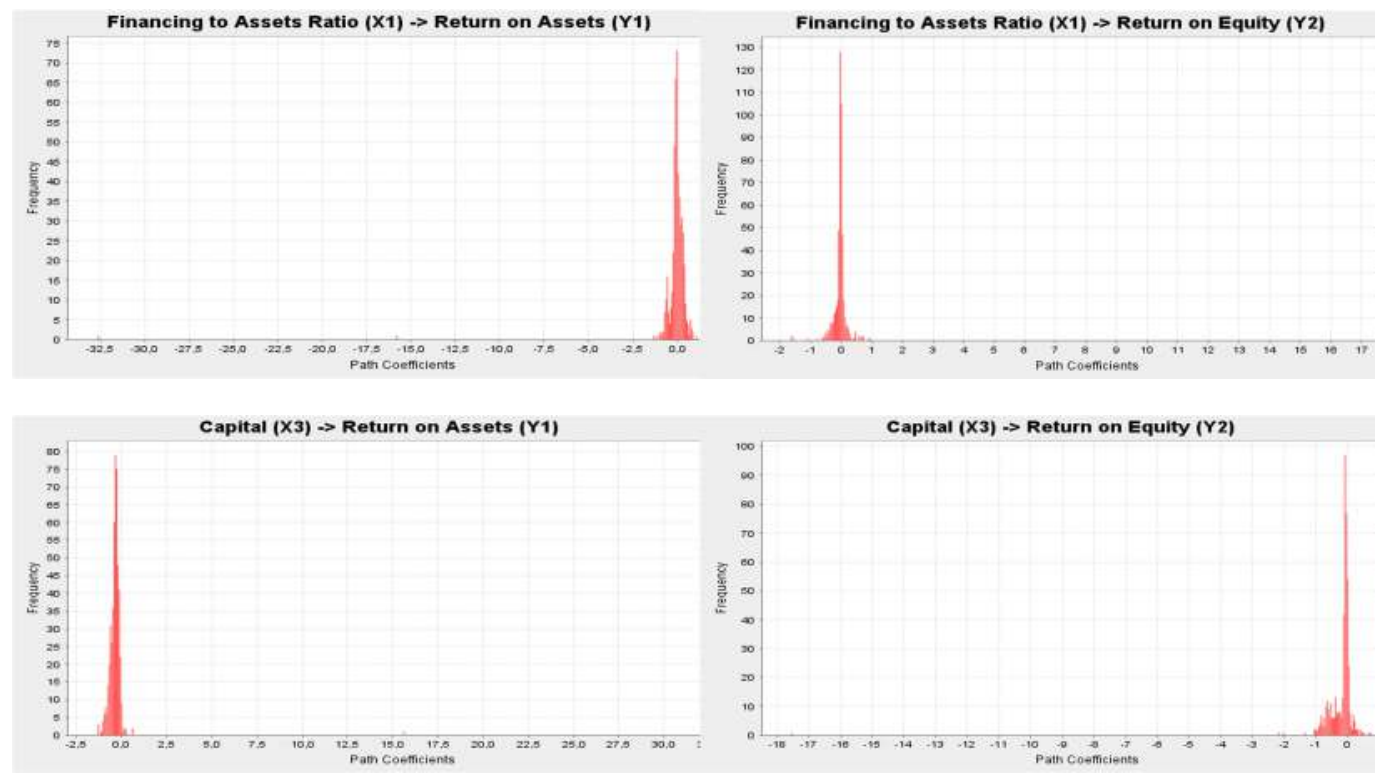

Fig. 2. Profitability Graph

Based on Figure 2, the strength of the dimensions that make up the latent factors can be tested using the Critical Ratio of the regression weight generated by the model. CR identity is seen by $\mathrm{t}$ value in the regression analysis. CR greater than 2.0 showed that the variables significantly the factors of dimension. Then the data in the analysis of this descriptive method with a qualitative approach. It is also indicated by the results of the PLS output with *** signs, indicate the probability of below $5 \%$ alpha. Fundamental analysis is a fundamental analysis to explore information including economic conditions, the industry as a whole, and the condition of the company. This analysis technique tends to consider performance and company projections to estimate stock prices. The initial method commonly used is first to capture stocks that are estimated to have feasibility. This can be done with a top-down step, which is to conduct observations starting from macroeconomic conditions, industrial sectors, to companies. Or it could also be done the opposite which is termed bottom-up, which is observing which starts from the company, the industrial sector, to macroeconomic conditions. 
In practice, there are several things that investors must know about the company that issued the shares. Although it can be known through a table issued by the company, investors can also dig up information about the company's financial and transparency elements. The achievement of results (performance) can be assessed according to the actors, namely Individual performance that describes how far someone has carried out their main tasks so that they can provide results that have been determined by groups or agencies. Group performance, which describes how far someone has carried out their main tasks so that they can provide results that have been set by the group or agency. Organizational performance, which describes how far one group has carried out all the main activities so as to achieve the vision and mission of the institution. Program performance, which is related to how far the activities in the program have been carried out so as to achieve the objectives of the program. Financial elements that need to be considered, such as income per share, book value of equity, book value of shares, or expenditure ratio. All of that will be needed to assess whether the stock is good or bad. Regarding information transparency, the company has prepared it in the annual report. In the report, all company activities are contained for one year. However, usually this annual report is sometimes difficult to understand. In essence, with the annual report, you can learn various things, such as weaknesses in the management structure, earnings information, and similar information.

If fundamental analysis tends to be more on the analysis of fundamental factors, technical analysis emphasizes the use of historical data regarding changes in stock prices, trading volumes and other market indicators. Actually, technical analysis is commonly used on stock exchanges, commodity exchanges, or other markets that are affected by demand and supply. By using technical analysis, analysts or investors take advantage of market data, such as stock prices, supply and demand in the past and trading volume. Trading volume data is often a special consideration in finding a general picture of market conditions to more easily predict future price trends. In practice, there are several things that investors must know about the company that issued the shares. Although it can be known through a table issued by the company, investors can also dig up information about the company's financial and transparency elements. Financial elements that need to be considered, such as income per share, book value of equity, book value of shares, or expenditure ratio. All of that will be needed to assess whether the stock is good or bad. Regarding information transparency, the company has prepared it in the annual report. In the report, all company activities are contained for one year. However, usually this annual report is sometimes difficult to understand. In essence, with the annual report, you can learn various things, such as weaknesses in the management structure, earnings information, and similar information.

\section{Conclusions}

The results show that the profitability of finance companies in Indonesia has decreased in the graph of financing profitability in the previous period.

\section{References}

[1] Arthur, W. B. et al. (1997) 'Asset Pricing Under Endogenous Expectations in an Artificial Stock Market', SSRN Electronic Journal. doi: 10.2139/ssrn.2252.

[2] Edwards, R. D., Magee, J. and Bassetti, W. H. C. (2018) Technical Analysis of Stock Trends. 8th edn. CRC Press LLC. 
[3] Herawati, A. and Putra, A. S. (2018) 'The Influence of Fundamental Analysis on Stock Prices: The Case of Food and Beverage Industries', European Research Studies Journal, 16(3), pp. 316-326. Available at: www.idx.co.id (Accessed: 24 January 2019).

[4] Hu, Z. et al. (2017) 'Listening to Chaotic Whispers: A Deep Learning Framework for News-oriented Stock Trend Prediction', Social and Information Networks, pp. 261-266. Available at: http://arxiv.org/abs/1712.02136 (Accessed: 24 January 2019).

[5] Namdari, A. and Li, Z. S. (2018) 'Integrating Fundamental and Technical Analysis of Stock Market through Multi-layer Perceptron', in 2018 IEEE Technology and Engineering Management Conference (TEMSCON). IEEE, pp. 1-6. doi: 10.1109/TEMSCON.2018.8488440.

[6] Soon, G. K. et al. (2018) 'A CIMB Stock Price Prediction Case Study with Feedforward Neural Network and Recurrent Neural Network', Journal of Telecommunication, Electronic and Computer Engineering, 10(3), pp. 90-94. Available at: http://journal.utem.edu.my/index.php/jtec/article/viewFile/4717/3465 (Accessed: 24 January 2019).

[7] de Souza, M. J. S. et al. (2018) 'Examination of the profitability of technical analysis based on moving average strategies in BRICS', Financial Innovation. Springer Berlin Heidelberg, 4(1), p. 3. doi: 10.1186/s40854-018-0087-z.

[8] Utami, W., Nugroho, L. and Farida (2017) 'Fundamental Versus Technical Analysis of Investment: Case Study of Investors Decision in Indonesia Stock Exchange', The Journal of Internet Banking and Commerce. ARRAY Development, 22(8), pp. 1-18. Available at: $\quad$ http://www.icommercecentral.com/open-access/fundamental-versus-technicalanalysis-of-investment-case-study-of-investors-decision-in-indonesia-stockexchange.php?aid=86055 (Accessed: 24 January 2019).

[9] Yahya, I., Torong, M. Z. B. and Muda, I. (2017) 'Influence behavior in legislature budget development of regions in the province of aceh and North Sumatra', International Journal of Economic Research, 14(8), pp. 147-156. 